\title{
Sand and The City: \\ The historical geography of sand mining in Jeneberang River and its relation to urban development in South Sulawesi
}

\author{
Dwiyanti Kusumaningrum ${ }^{1 *}$, Tria Anggita Hafsari ${ }^{1}$, Lukman Syam ${ }^{2}$ \\ ${ }^{1}$ Research Center for Population Studies, National Research and Innovation Agency (BRIN), Indonesia. \\ 2 Universitas Islam Negeri (UIN) Alauddin, Makassar, Indonesia.
}

${ }^{*}$ Corresponding author: dwiyanti.kusumaningrum@gmail.com

\begin{tabular}{|c|c|}
\hline ART & ABSTRACT \\
\hline $\begin{array}{l}\text { Keywwords: } \\
\text { Geology; Geomorphology; } \\
\text { Jeneberang; Sand Mining; } \\
\text { Urban Development. } \\
\text { How to cite: } \\
\text { Kusumaningrum, D., } \\
\text { Hafsari, T.A., Syam, L. } \\
\text { (2021). Sand and The } \\
\text { City: The historical } \\
\text { geography of sand mining } \\
\text { in Jeneberang River and its } \\
\text { relation to urban } \\
\text { development in South } \\
\text { Sulawesi. ETNOSIA: } \\
\text { Jurnal Etnografi } \\
\text { Indonesia. 6(2), } 200 \text { - } 216 . \\
\text { DOI: } \\
\text { 10.31947/etnosia.v6i2.17918 }\end{array}$ & $\begin{array}{l}\text { This exploratory research aims to elaborate the historical geography of } \\
\text { sand mining in Jeneberang River and analyze its relation to urban } \\
\text { development in South Sulawesi. This paper attempts to } \\
\text { comprehensively explain and enrich the literature on Jeneberang start } \\
\text { from physical setting of Jeneberang River to the history of Makassar } \\
\text { and transformation of traditional houses to explain how sand perceived } \\
\text { as a commodity and how sand mining has developed. We use a } \\
\text { qualitative approach that emphasizes the interpretation of } \\
\text { spatiotemporal morphology of sandbanks in Jeneberang River and } \\
\text { investigate sand mining activities from time to time. The method } \\
\text { consists of a study of Jeneberang historical literature, spatiotemporal } \\
\text { analysis, in-depth interviews, and field observations. We find that } \\
\text { sands have started to become a commodity since urban development } \\
\text { began in South Sulawesi. With volcanic and marine sedimentary rocks } \\
\text { dominate the region and the braided river morphology, Jeneberang } \\
\text { River is rich of sand and gravel materials. The 'modern' architecture } \\
\text { brought by the Dutch and South Sulawesi rebellion in 1950 has } \\
\text { affected major transformation from wooden traditional houses to } \\
\text { concrete-building houses, which indirectly affect the sand mining } \\
\text { activities in Jeneberang. No more wooden and bamboo or palm leaves, } \\
\text { but sand and gravel for concrete materials. In the current context, } \\
\text { Makassar's rapid urbanization and economic growth in have increased } \\
\text { the demand of building materials from Jeneberang River. In addition, } \\
\text { rapid urbanization has also been changed the livelihoods of local } \\
\text { communities, especially in the suburb to cope with the urban } \\
\text { development. Many people who previously work as farmers are now } \\
\text { becoming sand miners because they perceive that sand mining is more } \\
\text { profitable than agriculture. }\end{array}$ \\
\hline
\end{tabular}




\section{Introduction}

Our lives have always depended on nature. Mankind battles nature and always gets stuff from it. But consumerism in the modern world has increased the need for further exploitation of natural resources which are limited from the very beginning. However, humans always have their ways to overcome the limited natural resources with various technologies. Although natural resources are abundant, humans will never stop exploiting nature by carrying out various technological interventions, both in traditional and modern ways.

The variety of human needs is strongly influenced by the times, where each time is a cultural event in which economic conditions have a direct impact on the construction of culture. The construction of culture is determined by five factors that form the flow of global culture: (1) technology, (2) media, (3) financial, (4) ethnic, and (5) ideologies (Ajidarma, 2020). This construction of culture has happened in various regions of the world, including Indonesia. During the Dutch colonial period, traditional values in various regions of Nusantara archipelago had slowly shifted to modern values brought by the Dutch colonial government (Roosmalen, 2015). One of the most obvious examples is the transition in the architecture, changing from vernacular architecture which usually use wooden and bamboo materials to Western or 'modern' architecture which demands a supply of concrete materials such as sand and gravel. This transition has also occurred not only in Java (see Lombard, 1996), but also in almost various regions in Indonesia, one of which is South Sulawesi, the focus of the research area in this paper.

South Sulawesi is one of the regions on the island of Sulawesi that has a unique physiography and is part of the Ring of Fire. This makes South Sulawesi rich in natural resources including ones that derived from volcanism activities, such as fertile soil, as well as sand and stone materials. One area that is rich in sand and gravel materials is the Jeneberang River, which carries sand deposits from the valley of Mount Bawakaraeng (which is part of the Lompobattang Volcano chain) to the river mouth in the Makassar City area.

In addition to its physical characteristics, Jeneberang River has an important role in the history of Makassar by being the center of power. In the 16th century, the 9th King of Gowa moved the royal capital from Kale Gowa (Tamalate, $7 \mathrm{~km}$ from river mouth) to Somba Opu located at the mouth of the Jeneberang River (Garassi') (Makkelo, 2020; Poelinggomang, 2016). Since then, the Jeneberang river has become a strategic route for trade and even smuggling in the past (Poelinggomang, 2016). At present, the Jeneberang River plays a role as a source of livelihood for the community, both for agriculture, clean water supply, as well as a source of income from sand mining activities (Arjan, Afifah, Patila, \& Anas, 2020; Aswan, Najamuddin, \& Bahri, 2020; Kementerian Pekerjaan Umum dan Perumahan Rakyat, 2015; Walsh, 2008).

This paper argues that sands in Jeneberang River have started to become a commodity since urban development began in South Sulawesi. Sand mining resources in the Jebenerang River have existed for a long time, but the economic benefits have only been seen after modernization in this area. In the past, sand mining resources were abundant, but the people around Jeneberang still work on a subsistence basis. The current urban 
development requires people to work not only in the agricultural sector but also in the mining sector because the demand for sand and gravel materials for urban development is increasing.

Previous literatures have explained about the Jeneberang region including those related to sand mining. These comprises the discussion of its geology and mining engineering (Arafat, Saleh Pallu, Maricar, \& Lopa, 2015; Baja, Ramli, \& Lias, 2009; Leterrier, Yuwono, Soeria-Atmadja, \& Maury, 1990; Putera, Munir, Achmad, \& Suhardi, 2020), the economic valuation of sand mining resources (Alam \& Samsir, 2020; Andi Arjan, 2019; Arjan et al., 2020), sand mining management (Anas, Suriamihardja, Pallu, \& Irfan, 2015; Asrib, Arfandi, Dirawan, \& Haryadi, 2019), stakeholder mapping and governance (Nuraeni, Muchdar, Basri, Jusoff, \& Muhammad Basri, 2013; Nurhikmah \& Yusran, 2021; Sabar, Salman, \& At, 2020; Sahide et al., 2019; Walsh, 2008), environmental degradation and disaster management (Hardjosuwarno, 2008; Marini, Baja, \& Sultan, 2014; Nurdin \& Kubota, 2018; Nurdin, Kubota, \& Soma, 2019; Solle, Mustafa, Baja, \& Imran, 2013; Sulfitra et al., 2019) and so on.

However, research that comprehensively discusses the historical geography of sand mining resources in Jeneberang and its relation to urban development in South Sulawesi is still lacking. Historical geography perspective is appropriate for analyzing the trajectory of sand mining in Jeneberang River and its relation to South Sulawesi development. The concept of historical geography perspectives has been discussed since early 20th century mostly by American and British geographers (Baker, 1979; Gilbert, 1932; Harris, 1991; Sauer, 1941). The main concept of historical geography study is to reconstruct the regional geography of the past, means that we should analyze the geographical complex in any given past period of history. In this study, we use this lens in attempt to reconstruct the geographical scene of Jeneberang region in the past and related it within different phases of development identified, both in the past and the present. We use many sources such as KITLV old maps archives to draw a picture of physical setting in the past, historical literatures and other literatures, field observation and in-depth interview to triangulate the data.

Therefore, this paper attempts to comprehensively explain and enrich the literature on Jeneberang, especially the physical geography of Jeneberang River, sand mining and its relation to urban development in South Sulawesi.

\section{Methods}

This exploratory research aims to elaborate the historical geography of sand mining in Jeneberang River and analyze its relation to urban development in South Sulawesi. We use a qualitative approach that emphasizes the interpretation of spatiotemporal morphology of Jeneberang River and investigate sand mining activities from time to time. The methods consist of a study of Makassar-Gowa historical literatures, spatiotemporal analysis, in-depth interviews, and field observations.

This study used colonial maps archives as main source of data to draw a picture of physical setting in the past. Besides, we also use Google Earth's multitemporal satellite imagery, and aerial photography using drone to triangulate the distribution of sandbanks in Jeneberang River in the present time. In addition, we also conduct in-depth 
interviews to gather information about the history of sand mining activities and land use changes in the study area, the development of urban areas in South Sulawesi particularly Makassar City. For more detail below is the description of methods that we conducted:

\section{Collecting colonial maps archive}

The first step in reconstruction of the past of Jeneberang is collecting map archives. The maps that we use in this study are originated from the collections of the Royal Netherlands Institute of Southeast Asian and Caribbean Studies (KITLV), whose archives and library collections are now managed by the Universitaire Bibliotheken Leiden (UBL) since 2014. ${ }^{1}$ We are grateful that KITLV has made their collections especially Sulawesi region maps available online and available to use for the purpose of education and research. The Sulawesi region maps represented the geographical scene in the late $19^{\text {th }}$ century. Cartographic historian Ferjan J. Ormeling stated that systematic mapping on the island of Java was completed in 1880 and at the same time, triangulation began to be carried out in mountainous areas in Western Sumatra and Celebes (Sulawesi) (Ormeling, 2005). These maps provided administrative boundaries, roads, rivers, and a very accurate land use; consist of several commodity plantations (e.g., rubber, sugar, coffee, and bamboo), wet and dry paddy field, and the distribution of kampung. Each file of the 1:10.000 scale maps is a blad or sheet which still needs to be combined. This paper combines these sheets using digital graphic software and georeferenced it in ArcGIS software. The four blad used are as follow:

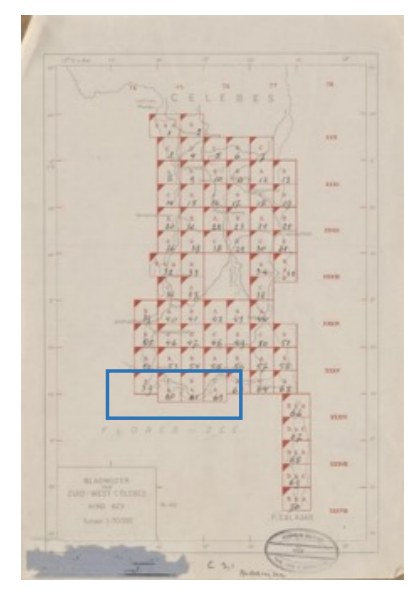

Image 1. Index sheet Bladwijzer van Zuid-West Celebes,

(Source: Universitaire Bibliotheken Leiden http://hdl.handle.net/1887.1/item:55656 , CC BY 4.0, modified by the author)

The second step is the collection of historical literatures of Makassar and Gowa region to comprehend the historical events that occurred in this region. These literatures are used to explain the logic of Jeneberang historical geography that we aim to reconstruct. We use historical books, scientific articles, online media articles, to enrich the discussion of this study.

1https://www.kitlv.nl/the-crowd-helps-unlocking-historical-maps-of-dutch-east-indies/accessed 8 October 2021 13:22pm 


\section{In depth interviews and field observations}

In this study, we did fieldwork at different times. During the fieldwork, we conducted in-depth interviews and field observations in the area around the Jeneberang River. Indepth interviews were conducted purposively by interviewing several traditional miners and residents living around the Jeneberang River. To verify some data regarding the physical aspects of Jeneberang, we also interviewed geologists to gain insight into the origin of the rock types used as building materials in the past. Field observation is also carried out by documenting the area using drones and cameras.

\section{Results and discussions}

In this section, we will explain the attributes of the physical geography of Jeneberang River using historical maps and literature review before explaining how sand perceived as a commodity and how sand mining has developed. This section consists of four subsections: (1) attributes of the physical geography of Jeneberang River (3) the history of Makassar and the transformation of South Sulawesi houses, 4) the sand mining livelihood: from traditional to modern mining and 5) the trajectory of sand mining and urban development.

\section{- Attributes of the Physical Geography of Jeneberang River}

One informant in our survey stated that Jeneberang River is a magical being. The river material is continuously flowing and provides benefits to humans. He also said the Jeneberang river can tell which channel is the right one, so it can turn (the channel) right or left. This is such an interesting statement, and we feel the need to investigate this further. Thus, we have interpreted the geological map, historical maps, and the available literature about geology and geomorphology of Jeneberang to find the scientific reasons for this statement and further explain why Jeneberang is rich in sand and gravel.

Geologically, the upstream area of Jeneberang consists of volcanic rocks. The headwaters of the Jeneberang River are in the valley of Mount Bawakaraeng which is also part of the Mount Lompobattang area, the highest volcano in the southern region of Sulawesi. This volcano forms the geology of the upstream region with volcanic rocks such as conglomerate, lava, breccia, lava deposits, and tuff and interbedded with marine sedimentary rocks in the middlestream area (Sukamto \& Supriatna, 1982). In terms of physiography, this mountain is a node of the synclinorium in the South Sulawesi region (Sandy, 1985). Although there have been no recorded eruptions in at least the last 10,000 years (Smithsonian Institution, 2021; Volcano Discovery, 2021), the upstream area of the Jeneberang river still carries volcanic materials in the form of sand and gravel. In fact, Jeneberang River has the highest maximum river discharge among the 20 major rivers in the South Sulawesi region, which is 315, $20 \mathrm{~m} 3 / \mathrm{s}$ (Kementerian Pekerjaan Umum dan Perumahan Rakyat, 2015). With the highest river discharge and geological characteristics where volcanic and marine sedimentary rocks dominate the region, Jeneberang River is rich of sand and gravel materials. 


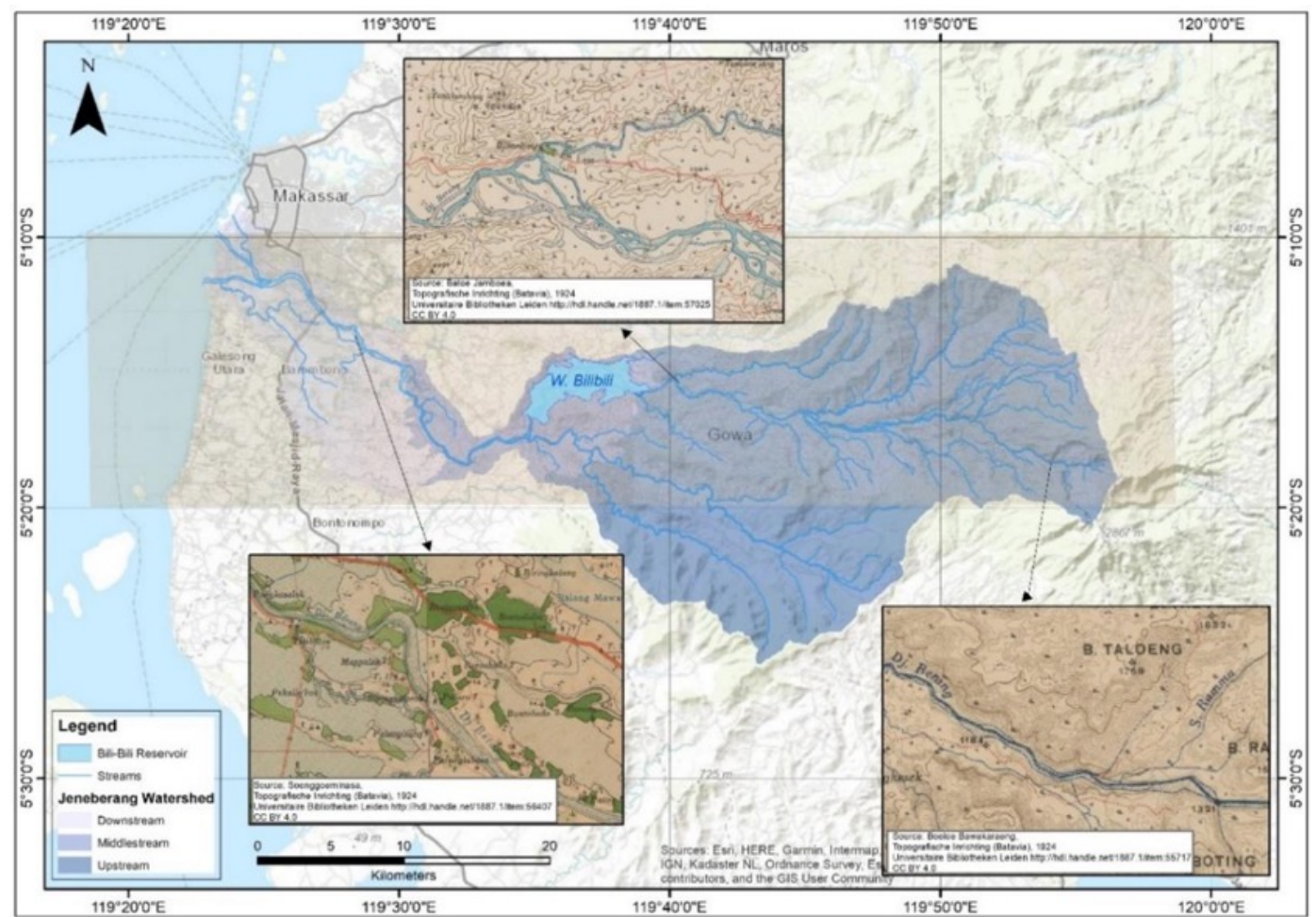

Image 2. The distribution of sandbanks in Jeneberang River based on historical maps. The map in the middle-stream shows the braided pattern of Jeneberang River. (Source: Author provided)

Based on its geomorphology, the Jeneberang is a braided river. Generally, braided rivers have numerous channels that split off and rejoin each other to give a braided pattern. This river pattern is characterized by abundant supply of sediment and high stream gradient. Theoretically, braided rivers can be distinguished according to their stage of evolution and the human and ecological benefits which are resulted directly from the relation between sediment supply and braiding intensity; that is expansion phase and contraction phase (Piégay, Grant, Nakamura, \& Tustrum, 2006).

According to the stage of river geomorphology, Jeneberang River is in the expansion phase, that is when the river typically aggrades and widens when sediment supply is high, thereby progressively occupying more riverbanks. The braided pattern of Jeneberang can be seen clearly at the 1920's historical map of Jeneberang when human activities did not necessarily affect the channel's braided pattern. Since the 1950s, the cumulative effect of human activities, massive land use changes, and human technological interventions (infrastructures e.g reservoir, dykes, and sand pocket) have lowered the braiding intensity. In addition, based on its high river discharge and river gradients, the Jeneberang braided pattern changed to a meandering single channel in the downstream (see Image 1). 


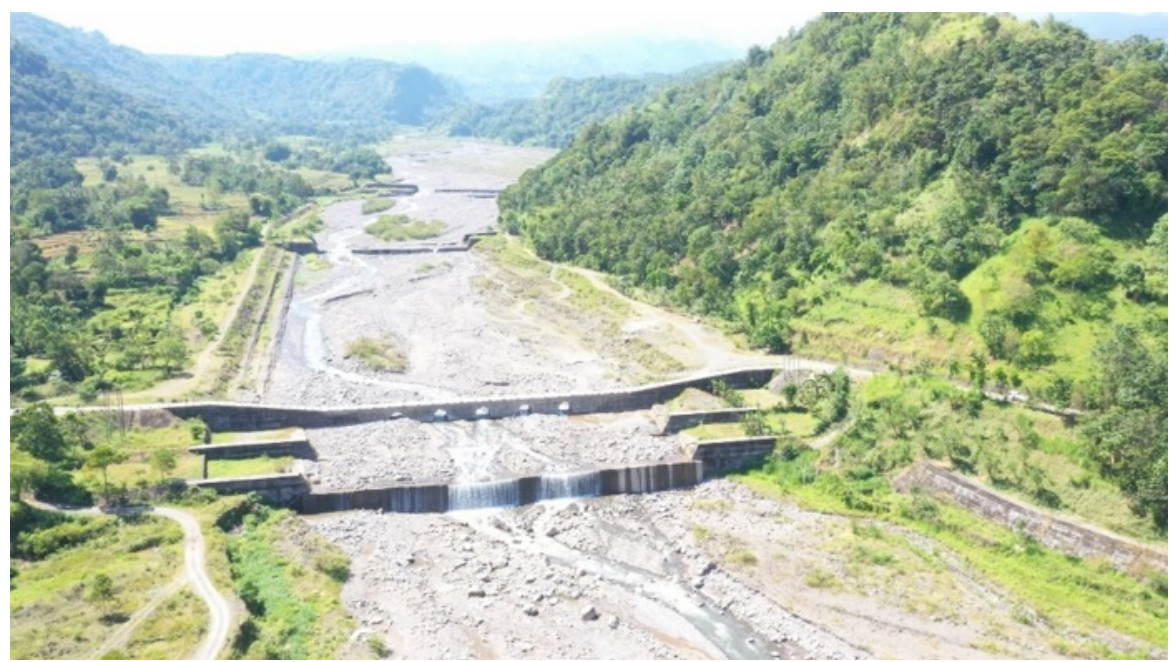

Image 3. The sand pocket in middle-stream area of Jeneberang River

(Source: Author provided)

The middle stream area of the Jeneberang river is the area most exploited by sand mining activities. We now understand that the Jeneberang River is not widening merely because of mining but the natural processes that work in this river. The riverbank area which tends to be wide and flat with sand and stone materials is the reason why sand mining is easy and widely carried out on Jeneberang River.

\section{- The history of Makassar and the transformation of South Sulawesi houses}

Beside the geographical characteristics, the massive activity of sand mining in the Jeneberang River cannot be separated from South Sulawesi's urban history. This is closely related to the history of Makassar as the center of economic and political activities since Makassar Kingdom (Gowa-Tallo) era. Therefore, in this section we try to explain the sand mining from historical perspectives. This section will explain about the history of Makassar, the transformation of traditional houses, and how this affects the need of concrete building material in South Sulawesi.

In the historiography of South Sulawesi, the Makassar Kingdom was very powerful, especially during the 16th to 17th centuries (Makkelo, 2020). At that time, the center of the kingdom was in Somba Opu, which is near the river mouth of Jeneberang. The Makassar Kingdom which was previously a port city was marked by the establishment of its royal center in Somba Opu, surrounded by Mangalekanna villages, and around this fort there were also trading offices as well as residences called Bontoala (Matullada, 1982). The arrival of the Dutch in the early $18^{\text {th }}$ century caused the destroy of Benteng Somba Opu as the center of the Kingdom. The Dutch then chose Ujung Pandang fort (Makassar City) as the hub of power, trade and military which later changed its name to Fort Rotterdam (Matullada, 1982). Thus, the fall of the kingdom of Gowa Tallo by the Dutch caused the transfer of power from Somba Opu to Fort Rotterdam in Makassar City (Reid, 2009).

Both during the reign of the Gowa-Tallo Kingdom and during the Dutch colonial period, there were fortress that were built at that time. In the past sixteenth century, brick fortifications have been built in South Sulawesi (Makkelo, 2020; Pelras, 2003; Sumalyo, 2002). Until now, these forts still exist and have become artifacts and cultural heritage. It 
is presumed that the forts were built from stones that have been taken from the river (Dariati, 2005). This statement is in accordance with the study of archaeological remains based on the geological study of the Kingdom of Gowa, which states that all building materials (clay, sandstone, andesite) were taken from around the center of the kingdom (downstream of Jeneberang River), except limestone from Maros and Pangkep areas and coral from the waters of the Makassar Strait (Intan, 1995). Historical records also state that on August 9, 1634 the King of Gowa XIV built a wall with black sandstone imported from the Gowa area, as well as rocks and bricks using lime and sand as adhesives (Kemdikbud, 2010).

Beside Fort Rotterdam, the Dutch colonial also began to build settlements in 1613 as the beginning of the growth of Makassar (Sumalyo, 2002). It is also revealed that Dutch colonial settlements in Makassar, like in other colonial cities in Indonesia, was started from within the forts, or called intra muros (Sumalyo, 2002).

In addition to building permanent settlements around the Fort of Rotterdam, the Dutch colonial government which had already occupied South Sulawesi built a small town in Malino (Gowa). Malino was not originally a kampong or settlement, but a flat area with reeds in the middle of the hills; this can be seen from the contours on the colonial map, where the contour lines are spaced apart (see Image 3). According to our informant and also the literature, the local villagers in the past used to call it lapparak ( $\sim \sim \curvearrowright)$ which in Makassarese means flat (Rijal, Bosra, \& Rasyid, 2018).

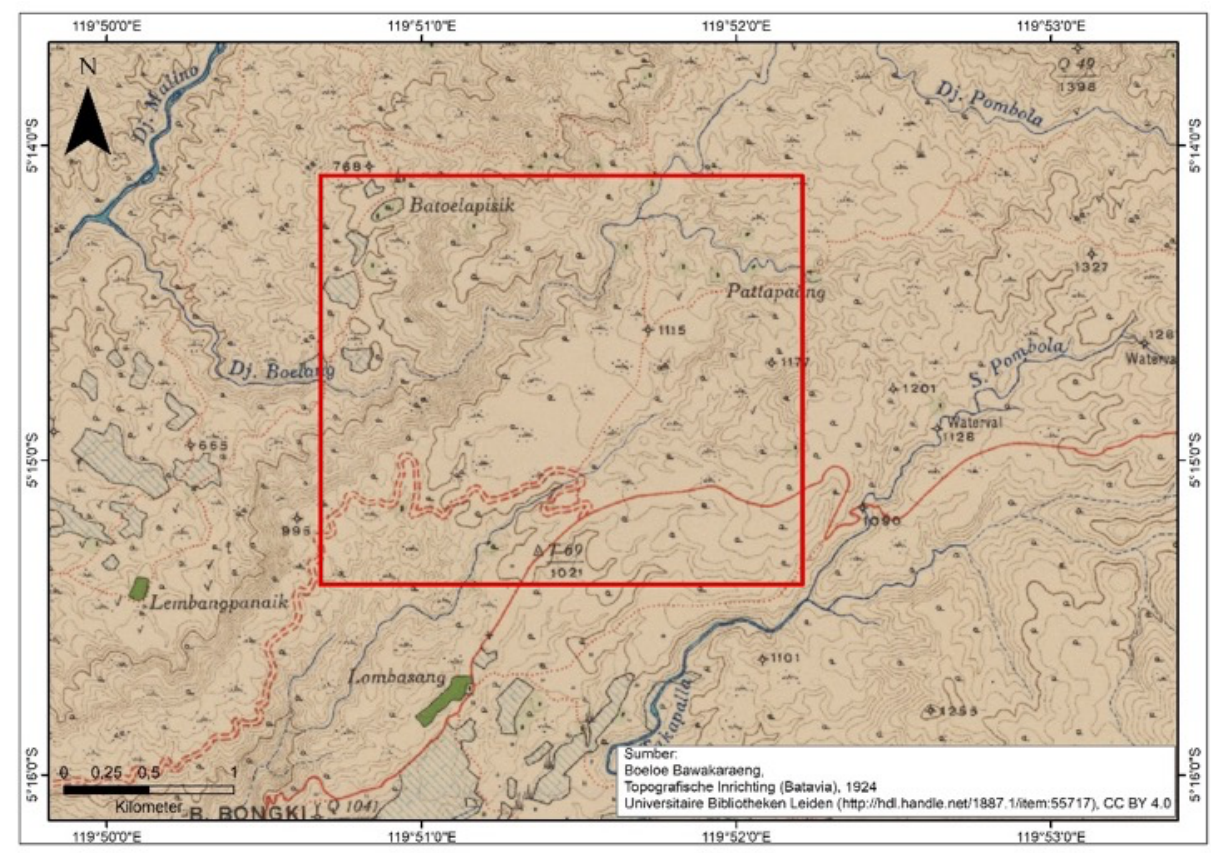

Image 4. Malino was previously a flat area with reed vegetation

(Source: map sheet Boeloe Bawakaraeng, Universitaire Bibliotheken Leiden

http://hdl.handle.net/1887.1/item:55717, CC BY 4.0, map layout processed by the author)

Historically, the city was built in 1927 by the Dutch colonial government as a resting place for colonial government employees. The grid-based road network with Spathodea flower trees on both side of the road is proof that this small town is an "artificial" city that was built with planning; unlike organic city in general (Kusumaningrum, 2021). It 
is undeniable that since the Dutch colonial period, massive urban development has already started. During this period, several Dutch settlements used sand and gravel as construction materials. While the indigenous people still living in their traditional wooden houses.

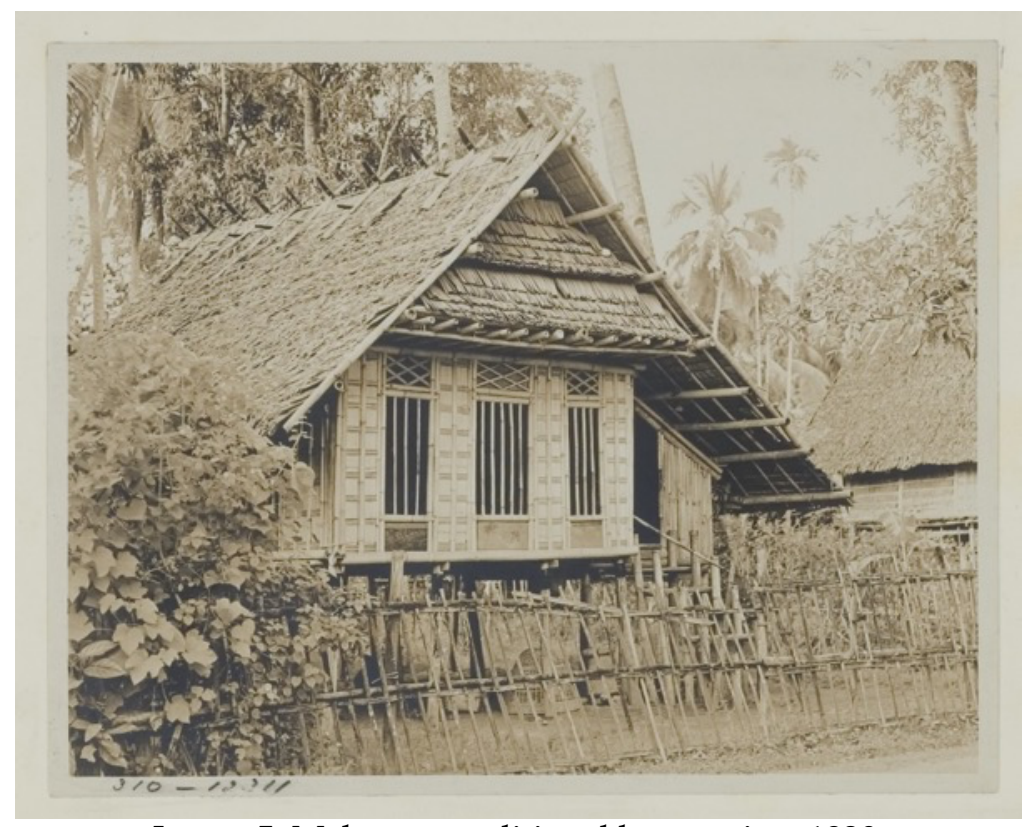

Image 5. Makassar traditional house, circa 1920

(Source: KITLV Digital Collections http://hdl.handle.net/1887.1/item:781936, CC BY 4.0)

The traditional houses in South Sulawesi (the Buginese, the Makassar, and the Mandar) have almost the same feature which usually use wood and bamboo as the main materials (Departemen Pendidikan dan Kebudayaan, 1984; Pelras, 2003). According to Pelras (2003), the type of construction of the Bugis and Makassar houses is almost the same as the construction of houses in Southeast Asia. The houses are constructed on top of wooden pillars to avoid the wet soils and the disturbance of wild animals (Departemen Pendidikan dan Kebudayaan, 1984). These traditional wooden houses do not require sand as in concrete-built houses. The availability of traditional building materials (wood, bamboo, and vegetal covering such as palm leaves (rumbia), sugar palm fiber) were abundant noting that the land use of the area of South Sulawesi based on 1924 colonial maps were still covered with vegetations such as palm, sugar, and bamboo trees.

Building houses for South Sulawesi people is closely related to their belief and religion (Departemen Pendidikan dan Kebudayaan, 1984; Syarif, Yudono, Harisah, \& Sir, 2018). For example, the front of the terraced roof of the Bugis house is part of an ancient belief that has a meaning for the life strata of the owner of the house (Pelras, 2003;Syarif, Yudono, Harisah, \& Sir, 2018). The front part of the roof for the Bugis is known as the timpalaja or sambulayang arrangement (Rahmansah \& Rauf, 2014). During the interview, the informant said that although the current building is more permanent/modern, the uniqueness of the roof which symbolizes the caste of the homeowner is still preserved. Thus, the modern and traditional architecture is somewhat coexisted. Even government buildings have sambulayang roofs (Rahmansah \& Rauf, 2014). In general, the BugisMakassar community consists of three layers, namely: wija arung (nobles), to sama/to 
maradeka (people), wija ata (servants of sahaya). A person with noble status may live in a saoraja (king's palace) or may build a house of the same size as a saoraja (Rahmansah \& Rauf, 2014). The ridge cover (timpalaja) is up to five levels.

The turning point for modern evolution of neo-traditional Bugis and Makassar houses occurred between 1950-1960 during the South Sulawesi Rebellion era (Pelras, 2003). During Indonesian post-independence, there was a rebellion from several nonaristocratic groups who rejected the existing hierarchical system. The group even suspected that the Bugis and Makassar aristocrats conspired with the Dutch colonials to create this hierarchical system. The group who refused to do so carried out anarchist actions by burning noble residences including traditional houses in South Sulawesi. Not only attacking the Bugis-Makassar and Dutch colonial aristocrats, but the local community also became victims of the riots at that time. So many houses were destroyed, including traditional houses.

During the New Order era, people began to rebuild their houses in a more 'modern' way, from wood and baboo raised-floor houses to brick and concrete buildings at ground level (Pelras, 2003). So that in the 1960s people began to build permanent houses and maintain the roof while still using the tambulayang symbol. It was during this period that the need for sand and gravel materials increased because of the rebuilding of houses burned by the rebellion. Until now, we can still observe the Bugis and Makassar traditional houses throughout the city of Makassar and its surroundings.

Now we understand that sand has started to become a commodity since urban development began in South Sulawesi, especially after 1950. In addition to modern architectural styles, the increasing population also affects land use which indirectly affects the availability of vegetal building materials, so South Sulawesi houses have been no longer built using wood, bamboo, and vegetal leaves, but a concrete building by maintaining the traditional features of Bugis Makassar houses, especially for people of noble descent.

\section{- The sand mining livelihood: from traditional to modern mining}

Along with the regional development of South Sulawesi, sand mining has become a livelihood for local communities in Gowa beside agricultural sector. Rapid urbanization and economic growth in Makassar urban area have been changing the livelihoods of local communities especially in the suburb to cope with the urban development. Many people who previously work as farmers are now becoming sand miners because they perceive that sand mining is more profitable than agriculture. These activities on the Jeneberang River were first carried out traditionally. Until now, traditional mining still can be found in several areas, including Bontomarannu District, Pallangga District, Sungguminasa District.

In general, traditional mining processes in the Jeneberang River include prospecting, exploration, exploitation, processing and refining, and distribution. Traditional miners usually obtain information on the existence of minerals from generation to generation or from those who did the sand mining first. Therefore, there is no certainty of sources explaining who did the prospecting for the first time. The exploration process of sand miners on the Jeneberang river is still very traditional using to'do or bamboo. The 
exploration process is carried out by two or three miners, using to' do to ensure the natural location of the sand piled up by the river discharge at several points in the middle of the river channel (Syam, 2016). The to'do, besides being used as a measuring tool, is also used as a holder for the divers.

Then, the exploitation stage process is also carried out in a traditional way. Some of the divers used a funnel that was tied to dig the sand that had accumulated at the bottom of the river, the funnel was made by themselves using iron material. The dredging activity is carried out repeatedly until the boat's capacity is full without using standard diving equipment. In addition to the limitations of tools, traditional sand mining also has several limitations including human resources, work safety guarantees, and aspects of the legality of permits.

When compared to modern mining, the depth of the river in the traditional mining remains stable to accommodate river discharge. This kind of process will provide an ecological balance between humans and the environment. In the case of sand mining in the Jeneberang River, the sand dredging process is carried out in the traditional way, namely using to'do, corong (funnel), and wooden boats (see Image 6). In practice, traditional miners tend to try to preserve river boundaries by mining the sand in the middle of the river channel.

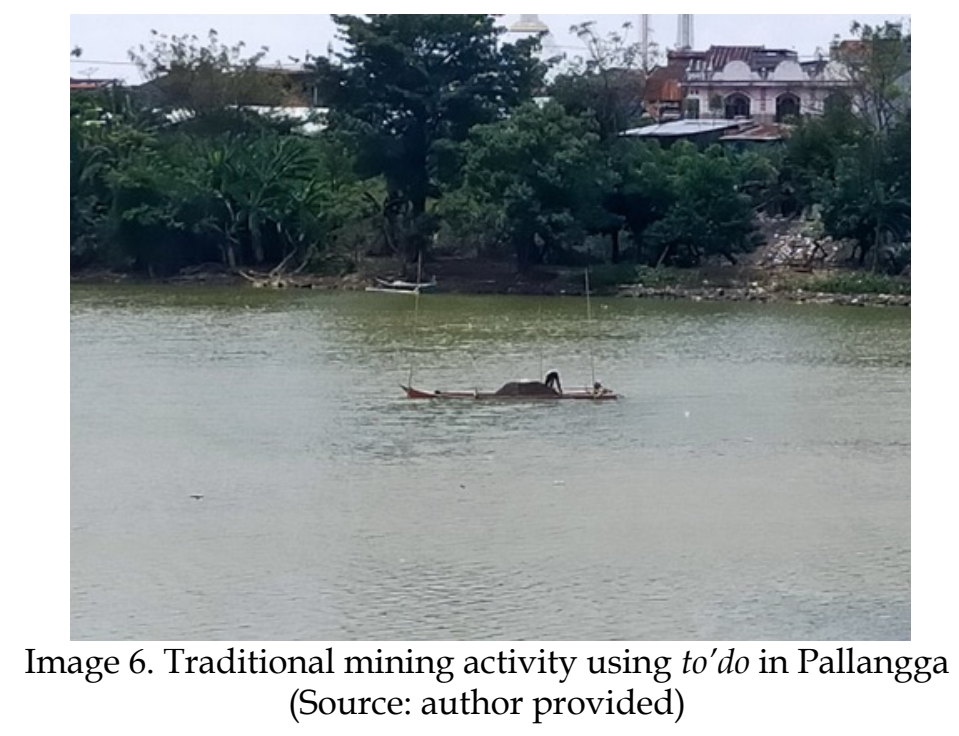

In terms of traditional mining, traditional miners are unable to meet market demand, so traditional sand miners take their supply of sand from modern mining. Thus, traditional mining activities do not carry out excessive dredging of material which is bad for the river ecosystem. Modern mining such as PT. Bumi Sarana Beton (BSB), a subsidiary of the Kalla Group based in Makassar, PT. Sinar Jaya Abadi (SJA), a subsidiary of PT. CISCO based in Makassar, and PT Bima Moriesya Anugerah which are mining companies that operate in Lonjoboko Village, Gowa Regency are the main supplier that can dominate more markets than traditional miners (Aswan et al., 2020).

Traditional miners tend to be able to survive with a well-targeted exploration process so that more mines can be produced. In addition, to preserve the river, the sand mining process is also attempted to be carried out on a limited scale. The challenges of traditional 
mining on the Jeneberang river include limited sand mining materials, tidal water, and rainfall that can cause flooding, thus hampering the entire process of mining sand from the riverbed.

Currently, the selling price of sand varies depending on the type of truck. The price of sand for small trucks is sold for 450.000 rupiahs, while for large trucks it is sold for 600.000 rupiahs. Consumers are usually sand collectors from within Makassar City and Gowa Regency. The sand mined from the Jeneberang River is used for the construction of houses, supplies for companies such as foundries, asphalt, and concrete companies.

- The trajectory of sand mining and urban development in South Sulawesi

The Jeneberang River has become the source of construction materials supply to fulfil the demand in Gowa Regency and Makassar City (Anas et al., 2015; Andi Arjan, 2019). Based on previous study, mining activities has been operating for more than 19 years in the Jeneberang River with 35 construction materials mining in Gowa Regency (Arjan et al., 2020). The rapidly growing demand for building materials in urban areas makes the demand for sand and gravel increase(Aswan et al., 2020).

The increasing population in Makassar and its suburban areas is associated with a decrease in agricultural land and an increase in building density (Surya et al., 2021). The rise of property sector, including large-scale housings and CBD development in the suburb of Makassar City has also increased the demand of building materials from Jeneberang River. In addition, urban facilities, and infrastructure in Gowa, Makassar City and other places in South Sulawesi have been supported from the sand and gravel supplies from Jeneberang River. Mining material is used for paving roads, building the Sulawesi railway, and housing construction, both subsidized and commercial housing.

Table 1. Trajectory of sand mining and urban development in South Sulawesi

\begin{tabular}{|c|c|c|}
\hline $\begin{array}{l}\text { Period/Phase of } \\
\text { Development }\end{array}$ & Identified Site and Situation & $\begin{array}{l}\text { Supporting } \\
\text { literatures }\end{array}$ \\
\hline $\begin{array}{l}\text { Gowa Kingdom (16 th } \\
\text { to } 17^{\text {th }} \text { century) }\end{array}$ & $\begin{array}{l}\text { - In the 16th century, the 9th King of Gowa } \\
\text { moved the royal capital from Kale Gowa } \\
\text { (Tamalate, 7km from river mouth) to Somba } \\
\text { Opu located at the mouth of the Jeneberang } \\
\text { River } \\
\text { - The Jeneberang River has become a symbol } \\
\text { of power and strategic route for trade. } \\
\text { - On August 9, 1634, the King of Gowa XIV } \\
\text { built a wall with black sandstone imported } \\
\text { from Gowa region as well as rocks and bricks } \\
\text { using lime and sand as adhesives. } \\
\text { - Jeneberang River become the source of } \\
\text { construction materials for fortifications } \\
\text { during Gowa Kingdom's development era. }\end{array}$ & $\begin{array}{l}\text { (Makkelo, 2020; } \\
\text { Poelinggomang, } \\
\text { 2016) }\end{array}$ \\
\hline $\begin{array}{l}\text { VOC - The Dutch } \\
\text { Colonial period }\left(17^{\text {th }}\right. \\
\text { century to } 20^{\text {th }} \\
\text { century) }\end{array}$ & $\begin{array}{l}\text { - VOC began to build modern settlements in } \\
1613 \text { as the beginning of the growth of } \\
\text { Makassar. } \\
\text { - In 1927, the Dutch Colonial built a small } \\
\text { town in the upstream of Jeneberang (Malino, } \\
\text { Gowa). } \\
\text { - The traditional houses still existed. The } \\
\text { availability of traditional building materials }\end{array}$ & $\begin{array}{l}\text { (Pelras, 2003; } \\
\text { Sumalyo, 2002) }\end{array}$ \\
\hline
\end{tabular}




\begin{tabular}{|c|c|c|}
\hline & $\begin{array}{l}\text { (wood, bamboo, and vegetal covering such as } \\
\text { palm leaves (rumbia), sugar palm fiber) were } \\
\text { abundant. } \\
\text { - Jeneberang River become the source of } \\
\text { construction materials during this period. }\end{array}$ & \\
\hline $\begin{array}{l}\text { Sulawesi Rebellion } \\
1950-1960\end{array}$ & $\begin{array}{l}\text { - Modern evolution of neo-traditional Bugis } \\
\text { and Makassar houses } \\
\text { - Sulawesi Rebellion caused many houses } \\
\text { were destroyed, including traditional houses. }\end{array}$ & (Pelras, 2003) \\
\hline $\begin{array}{l}\text { Post Rebellion/New } \\
\text { Order Era }\end{array}$ & $\begin{array}{l}\text { - People began to rebuild their houses in a } \\
\text { more 'modern' way, from wood and baboo } \\
\text { raised-floor houses to brick and concrete } \\
\text { buildings at ground level. } \\
\text { - The need for sand and gravel materials } \\
\text { increased because of the rebuilding of houses } \\
\text { burned by the rebellion. } \\
\text { - The increasing population also affects land } \\
\text { use which indirectly affects the availability of } \\
\text { vegetal building materials. } \\
\text { - Traditional mining activities identified in } \\
\text { 1980s. }\end{array}$ & (Pelras, 2003) \\
\hline Reform Era & $\begin{array}{l}\text { - Rapid urbanization and economic growth in } \\
\text { Makassar urban area (the rise of property } \\
\text { sector, including large-scale housings and } \\
\text { CBD development in the suburb of Makassar } \\
\text { City) demand construction materials for } \\
\text { urban development. } \\
\text { - The emergence of modern sand mining } \\
\text { occurred. There are } 35 \text { construction material } \\
\text { mining in Gowa Regency beside existing } \\
\text { traditional miners. } \\
\text { - It is estimated that the volume of sediment in } \\
\text { Jeneberang River until } 2020 \text { was } 199.2 \text { million } \\
\text { m }^{3} \text { with estimated economic valuation value } \\
\text { for about } 39,8 \text { to } 47,2 \text { trillion rupiahs. }\end{array}$ & $\begin{array}{l}\text { (Alam \& } \\
\text { Samsir, 2020; } \\
\text { Arjan, Afifah, } \\
\text { Patila, \& Anas, } \\
\text { 2020; Surya et } \\
\text { al., 2021) }\end{array}$ \\
\hline
\end{tabular}

\section{Conclusion}

Based on geological setting and geomorphology, we finally find the scientific reasons that explain why Jeneberang is rich in sand and gravel materials. With braided river morphology and its geological characteristics where volcanic and marine sedimentary rocks dominate the watershed, Jeneberang River has abundant supply of sand and stone materials. In addition, with the highest maximum river discharge among the 20 major rivers in the South Sulawesi region and high river gradient, Jeneberang River has naturally eroded the materials from the upstream to the downstream, making it rich of sediment materials such as sand and rocks.

Sands have started to become a commodity since urban development began in South Sulawesi. The 'modern' architecture brought by the Dutch and South Sulawesi rebellion in 1950 has affected major transformation from wooden traditional houses to concretebuilding houses, which indirectly affect the sand mining activities in Jeneberang. In the current development, Makassar's rapid urbanization and economic growth have 
increased the demand of sand and gravel materials from Jeneberang River. In addition, this has also changed the livelihoods of local communities, especially in the suburb to cope with the urban development. Many people who previously work as farmers are now becoming sand miners, both informally as traditional miners and labors for mining companies, because they perceive that sand mining is more profitable than agriculture.

Conflicts of Interest:

The authors declare that there is no conflict of interest.

Acknowledgement:

We would like to thank IPSK-LIPI, especially the National Research Priority- Natural Resources Management team for providing the opportunity and support to research Jeneberang Watershed in South Sulawesi. We also thank Kusnadi, MSc, geologist, who clearly explains Jeneberang geological interpretations during the research work.

\section{References}

Ajidarma, S. G. (2020). Doi Panggil Ogut Nyomet! :). In Affair: Obrolan Urban (pp. 153156). Yogyakarta: Pabrik Tulisan.

Alam, S., \& Samsir, A. (2020). Jeneberang Sediment Economic Valuation, Gowa District (SDGS Persfective). International Conference on Science and Advanced Technology (ICSAT), 1375-1382. Retrieved from

https:/ / scholar.google.com/citations?view_op=view_citation\&hl=en\&user=yTupY4AAAAJ\&pagesize=100\&citation_for_view=yT-upY4AAAAJ:UebtZRa9Y70C

Anas, A. V., Suriamihardja, D. A., Pallu, M. S., \& Irfan, U. R. (2015). Sustainable management strategy of construction materials mining in jeneberang river, south sulawesi. ARPN Journal of Engineering and Applied Sciences, 10(16), 6845-6851.

Andi Arjan. (2019). Econometric Model of Supply and Demand for Mining Construction Materials in the Jeneberang River, Gowa Regency, South Sulawesi. International Journal of Engineering Research And, V8(06), 1060-1062. https:// doi.org/10.17577/ijertv8is060555

Arafat, Y., Saleh Pallu, M., Maricar, F., \& Lopa, R. T. (2015). Morphology evolution of lower Jeneberang River, Indonesia. International Journal of Earth Sciences and Engineering, 8(5), 2011-2016.

Arjan, A., Afifah, A. N., Patila, Y. A., \& Anas, A. V. (2020). Valuation of Environmental Impact Due to Material Construction Mining, Gowa, South Sulawesi. EPI International Journal of Engineering, 3(1), 90-94. https:/ / doi.org/10.25042/epiije.022020.13

Asrib, A. R., Arfandi, A., Dirawan, G. D., \& Haryadi, F. (2019). Analysis Test of Fine Aggregates at the Upstream of Jeneberang River. Journal of Physics: Conference Series, 1244(1). https://doi.org/10.1088/1742-6596/1244/1/012039

Aswan, Najamuddin, \& Bahri. (2020). Usaha Tambang Pasir Batu di Desa Lonjoboko, Kabupaten Gowa, 2006-2018. Attoriolog Jurnal Pemikiran Kesejarahan Dan Pendidikan Sejarah, 18(1), 101-112.

Baja, S., Ramli, M., \& Lias, S. A. (2009). Spatial-based assessment of land use, soil erosion, and water protection in the Jeneberang valley, Indonesia. Biologia, 64(3), 522-526. https:// doi.org/10.2478/s11756-009-0074-y

Baker, A. R. H. (1979). Historical geography: a new beginning? Progress in Human Geography, (1973). Retrieved from https:/ / doi.org/10.1177\%2F030913257900300405

Dariati, T. (2005). Landscape Restoration: Aggregate Mining in the Jeneberang River 
Basin. In From Sky to Sea: Environment and Development in Sulawesi (Department, pp. 505-525). University of Waterloo.

Departemen Pendidikan dan Kebudayaan. (1984). Album Arsitektur Tradisional (Aceh, Sumatera Barat, Sulawesi Selatan, Nusa Tenggara Barat). Jakarta: Dirjen Kebudayaan, Departemen Pendidikan dan Kebudayaan.

Gilbert, E. W. (1932). What is historical geography? Scottish Geographical Magazine, 48(3), 129-136. https:/ / doi.org/10.1080/00369223208734833

Hardjosuwarno, S. (2008). Community Based Warning and Evacuation System against Debris Flow in the Upper Jeneberang River, Gowa, South Sulawesi. Forum Geografi, 22(1), 13. https:// doi.org/10.23917/ forgeo.v22i1.4922

Harris, C. (1991). Power, Modernity, and Historical Geography. Annals of the Association of American Geographers, 81(4), 671-683. https:/ / doi.org/10.1093/cr/50.2.545

Intan, F. S. (1995). Tinggalan Arkeologi Di Kerajaan Gowa Dan Tallo Berdasarkan Kajian Geologi Dan Lokasi Sumber Bahan. Berkala Arkeologi, 15(3), 173-176. https:// doi.org/10.30883/jba.v15i3.690

Kemdikbud. (2010). Benteng Rotterdam. Retrieved October 26, 2021, from http://cagarbudaya.kemdikbud.go.id/cagarbudaya/detail/PO2015071000005/b enteng-rotterdam

Kementerian Pekerjaan Umum dan Perumahan Rakyat. Pola Pengelolaan Sumber Daya Air Wilayah Sungai Jeneberang (2015). Indonesia.

Kusumaningrum, D. (2021). Sepenggal Cerita tentang Malino. Retrieved August 28, 2021, from https:// kependudukan.lipi.go.id/kajian-kependudukan/penduduklingkungan/sepenggal-cerita-tentang-malino/

Leterrier, J., Yuwono, Y. S., Soeria-Atmadja, R., \& Maury, R. C. (1990). Potassic volcanism in Central Java and South Sulawesi, Indonesia. Journal of Southeast Asian Earth Sciences, 4(3), 171-187. https:/ / doi.org/10.1016/S0743-9547(05)80011-X

Lombard, D. (1996). Nusa Jawa: Silang Budaya (Bagian I: Batas-Batas Pembaratan). PT Gramedia Pustaka Utama.

Makkelo, I. D. (2020). Sejarah Makassar dan Tradisi Literasi. Lembaran Sejarah, 15(1), 30. https:// doi.org/10.22146/lembaran-sejarah.59523

Marini, Baja, S., \& Sultan, I. (2014). Penerimaan informasi dampak penambangan pasir bagi kerusakan lingkungan hidup di kalangan penambang pasir ilegal di DAS Jeneberang Kabupaten Gowa. Jurnal Komunikasi KAREBA, 3(2), 112-118.

Matullada. (1982). Penelitian berbagai Aspek Keagamaan dalam Kehidupan Masyarakat dan Kebudayaan di Indonesia.

Nuraeni, Muchdar, A., Basri, L., Jusoff, K., \& Muhammad Basri, D. (2013). The influence of internal and external factors on Farmers' Perception and participation in jeneberang watershed conservation. World Applied Sciences Journal, 22(11), 16391643. https://doi.org/10.5829/idosi.wasj.2013.22.11.13028

Nurdin, P. F., \& Kubota, T. (2018). Gis-Based Landslide Susceptibility Assessment and Factor Effect Analysis By Certainty Factor in Upstream of Jeneberang River, Indonesia. Geoplanning: Journal of Geomatics and Planning, 5(1), 75. https:/ / doi.org/10.14710/geoplanning.5.1.75-90

Nurdin, P. F., Kubota, T., \& Soma, A. S. (2019). Investigation of flood and landslide in the Jeneberang catchment area, Indonesia in 2019. International Journal of Erosion Control Engineering, 12(1), 13-18. https:/ / doi.org/10.13101/ijece.12.13

Nurhikmah, U., \& Yusran. (2021). Stakeholder analysis in conflict managing: A case study of forest management Unit Jeneberang II. IOP Conference Series: Earth and Environmental Science, 681(1). https:/ / doi.org/10.1088/1755-1315/681/1/012008

Ormeling, F. (2005). Colonial Cartography of the Netherlands East Indies 1816-1942. Cartography. Utrecht.

Pelras, C. (2003). Bugis and Makassar houses: Variation and evolution. In R. Schefold, 
G. Domenig, \& P. J. M. Nas (Eds.), Indonesian Houses: Tradition and Transformation in Vernacular Architecture (KITLV, pp. 251-284). Leiden: KITLV Press.

Piégay, H., Grant, G., Nakamura, F., \& Tustrum, N. (2006). Braided river management: from assessment of river behaviour to improved sustainable development. In G. H. S. Smith, J. L. Best, C. S. Bristow, \& G. E. Petts (Eds.), Braided Rivers: Process, Deposits, Ecology and Management (pp. 257-275). Blackwell Publishings.

Poelinggomang, E. L. (2016). Makassar Abad XIX: Studi tentang Kebijakan Perdagangan Maritim (Second Edi). Jakarta: Kepustakaan Populer Gramedia (KPG). Retrieved from https:// play.google.com/books/reader?id=ZidIDwAAQBAJ\&pg=GBS.PA12

Putera, M. I., Munir, A., Achmad, M., \& Suhardi. (2020). Land use assessment of Jeneberang watershed using hydrology and water availability analysis. IOP Conference Series: Earth and Environmental Science, 473(1). https:/ / doi.org/10.1088/1755-1315/473/1/012099

Rahmansah, \& Rauf, B. (2014). Arsitektur Tradisional Bugis Makassar (Survei pada Atap Bangunan Kantor di Kota Makassar). Jurnal Forum Bangunan, 12(2), 56-63.

Reid, A. (2009). Pluralisme dan Kemajuan Makassar Abad ke-17.

Rijal, M., Bosra, M., \& Rasyid, M. R. (2018). Malino: Kota Perdamaian dan Kawasan Wisata di Gowa 1946-2002. Jurnal Pattingalloang, 5(1), 39. https:// doi.org/10.26858/pattingalloang.v5i1.7077

Roosmalen, P. K. M. van. (2015). Netherlands Indies Town Planning An Agent of Modernization (1905-1957). In F. Colombijn \& J. Cote (Eds.), Cars, Conduits, and Kampongs: The Modernization of the Indonesian City, 1920-1960 (Open Acces, p. 87). Leiden: Brill.

Sabar, H., Salman, D., \& At, M. R. (2020). Antropocentrism Epidemic : the Study of Social Action of Community To the Environment of Jeneberang River, 4(1), 37-48.

Sahide, M. A. K., Muliati, M., Samad, R. S., Mas'ud, E. I., Sabar, A., Yusran, Y., ... Fisher, M. R. (2019). Fragmented dual patrons: Analyzing regional bureaucracies' task and the coalition on governing Jeneberang watershed landscape. IOP Conference Series: Earth and Environmental Science, 270(1). https:/ / doi.org/10.1088/1755-1315/270/1/012043

Sandy, I. M. (1985). Geografi Regional Republik Indonesia. Jakarta: Geografi FMIPA UI.

Sauer, C. O. (1941). Foreword to Historical Geography. Annals of the Association of American Geographers, 31(1), 1-26. https://doi.org/10.1111/j.14678306.1979.tb01220.x

Smithsonian Institution. (2021). Lompobatang. Retrieved August 6, 2021, from https:/ / volcano.si.edu/volcano.cfm?vn=266807

Solle, M. S., Mustafa, M., Baja, S., \& Imran, A. M. (2013). Landslide Susceptibility Zonation Model On Jeneberang Watershed Using Geographical Information System and Analytical Hierarchy Process. Ijeit, 2(7), 174-179.

Sukamto, R., \& Supriatna, S. (1982). Geologic Map of the Ujungpandang, Benteng, and Sinjai Quadrangles, Sulawesi Scale 1:250.000. Bandung: Geological Survey of Indonesia, Ministry of Mines.

Sulfitra, A., Mirajanna, Saputra, R., Haidar, A., Ihsan, N., Arsenio, M., ... Sulaiman, M. A. (2019). Degrasi Lingkungan dan Bencana Ekologis di Sulawesi Selatan. Catatan Akhir Tahun WALHI Sulsel. Makassar.

Sumalyo, Y. (2002). Dutch Colonial Architecture and City Development of Makassar. DIMENSI (Jurnal Teknik Arsitektur), 30(1), 46-53. Retrieved from http://puslit2.petra.ac.id/ejournal/index.php/ars/article/view/15764

Surya, B., Salim, A., Hernita, H., Suriani, S., Menne, F., \& Rasyidi, E. S. (2021). Land use change, urban agglomeration, and urban sprawl: A sustainable development perspective of makassar city, indonesia. Land, 10(6). 
https:/ / doi.org/10.3390/land10060556

Syam, L. (2016). Dinamika Masyarakat Pertambangan (Studi Kasus pada Warga Desa Borisallo Kecamatan Parangloe Kabupaten Gowa). UIN Alauddin Makassar.

Syarif, S., Yudono, A., Harisah, A., \& Sir, M. M. (2018). Ritual Proses Konstruksi Rumah Tradisional Bugis Di Sulawesi Selatan. Walasuji : Jurnal Sejarah Dan Budaya, 9(1), 53-72. https://doi.org/10.36869/wjsb.v9i1.21

Volcano Discovery. (2021). Lompobatang volcano. Retrieved August 6, 2021, from https:/ / www.volcanodiscovery.com/lompobatang.html

Walsh, T. A. (2008). Decentralization and natural resource management: New opportunities for communities in the upper Jeneberang watershed, South Sulawesi, Indonesia? ProQuest Dissertations and Theses. Retrieved from

http:/ / search.proquest.com/docview/304600240?accountid=13771 